\title{
Mannosylated linear and cyclic single amino acid mutant peptides using a small 10 amino acid linker constitute promising candidates against multiple sclerosis
}

\section{Stephanie Day ${ }^{1}$,Theodore Tselios ${ }^{2}$, Maria-Eleni Androutsou $^{2,3}$, Anthi Tapeinou ${ }^{2}$, Irene Frilligou ${ }^{2}$, Lily Stojanovska ${ }^{4}$, John Matsoukas ${ }^{2,3}$ and Vasso Apostolopoulos ${ }^{4}$}

1 Immunology and Vaccine Laboratory, Burnet Institute, Melbourne, VIC, Australia

${ }^{2}$ Department of Chemistry, University of Patras, Patras, Greece

${ }^{3}$ Eldrug S.A., Patras, Greece

${ }^{4}$ Centre for Chronic Disease, College of Health and Biomedicine, Victoria University, Melbourne, VIC, Australia

\section{Edited by:}

Hans-Peter Hartung, Heinrich-Heine University Düsseldorf, Germany

Reviewed by:

William J. Karpus, Northwestern

University, USA

Reinhard Reuß, BKH Bayreuth,

Germany

\section{*Correspondence:}

Vasso Apostolopoulos, Centre for

Chronic Disease, College of Health and Biomedicine, Victoria University,

Melbourne, VIC, Australia

e-mail: vasso.apostolopoulos@vu. edu.au
Multiple sclerosis (MS) is a serious autoimmune demyelinating disease leading to loss of neurological function. The design and synthesis of various altered peptide ligands of immunodominant epitopes of myelin proteins to alter the autoimmune response, is a promising therapeutic approach for MS. In this study, linear and cyclic peptide analogs based on the myelin basic protein 83-99 (MBP ${ }_{83-99}$ immunodominant epitope conjugated to reduced mannan via the $(K G)_{5}$ and keyhole limpet hemocyanin $(K L H)$ bridge, respectively, were evaluated for their biological/immunological profiles in SJL/J mice. Of all the peptide analogs tested, linear $\mathrm{MBP}_{83-99}\left(\mathrm{~F}^{91}\right)$ and linear $\mathrm{MBP}_{83-99}\left(\mathrm{Y}^{91}\right)$ conjugated to reduced mannan via a $(\mathrm{KG})_{5}$ linker and cyclic $\mathrm{MBP}_{83-99}\left(\mathrm{~F}^{91}\right)$ conjugated to reduce mannan via $\mathrm{KLH}$ linker, yielded the best immunological profile and constitute novel candidates for further immunotherapeutic studies against MS in animal models and in human clinical trials.

Keywords: multiple sclerosis, mannan, myelin basic protein, $\mathrm{MBP}_{83-99}$, altered peptide ligands

\section{INTRODUCTION}

Multiple sclerosis (MS) is often a slowly progressive and chronic auto-immunologically mediated disease of the central nervous system (CNS), with inflammation around the myelin sheath (1-3). MS is primarily a T-helper 1 (Th1)-mediated disease, although Th17 cells also play a crucial role (4). Experimental autoimmune encephalomyelitis (EAE) is a commonly used experimental model of MS and represents an invaluable in vivo model for the evaluation of new immunotherapeutic approaches against MS. There is clear presence of autoreactive- $\mathrm{T}$ cells, which recognize encephalitogenic epitopes of myelin proteins, such as myelin basic protein (MBP), myelin oligodendrocyte glycoprotein (MOG), and proteolipid protein (PLP). These auto reactive $T$ cells and their secretion primarily of Th1 cytokines (IFN-gamma) play a pathogenic role in the induction of disease. One promising immunotherapeutic approach against MS, involves the design and use of mutated peptides of immunodominant myelin epitopes to divert Thl proinflammatory cytokines to an anti-inflammatory state to induce $\mathrm{T}$ cell tolerance. Studies have shown that $\mathrm{T}$ cell responses in patients are associated with the recognition of the 81-105 region of MBP $\left(\mathrm{Q}^{81}\right.$ DENPVVHFFKNIVTPRTPPPSQGK $\left.{ }^{105}\right)$, and with highest affinity and binding to HLA-DR2 (DRA, DRB1*1501) for $\mathrm{MBP}_{83-99}\left(\mathrm{E}^{83} \mathrm{NPVVHFFKNIVTPRTP}^{99}\right)(5-10)$. Although T cells from healthy individuals also recognize $\mathrm{MBP}_{83-99}$ the precursor frequencies are relatively low. The binding of $\mathrm{MBP}_{83-99}$ to HLA-DR2 is via hydrophobic $\mathrm{V}^{87}$ and $\mathrm{F}^{90}$ residues, and, $\mathrm{V}^{86}$, $\mathrm{H}^{88}, \mathrm{~F}^{89}$, and $\mathrm{K}^{91}$ being TCR contact residues (10-15). Residue $\mathrm{P}^{96}$ is also a TCR contact site based on the crystal structure of
HLA-DR2 $\alpha-\mathrm{MBP}_{89-101}$ complex (16). In a human phase II clinical trial in MS patients, substitution of the epitope $\mathrm{MBP}_{83-99}$, with several D-amino acids or Ala at the N terminal (NBI-5788, CGP77116) induced strong IL-5 and IL-13 cytokine responses; however, many patients developed dangerous side effects and the clinical trials were stopped $(17,18)$. These results indicated that further pre-clinical testing is required and new modified peptides need to be designed together with appropriate immunomodulatory adjuvants or carriers, for the peptide based immunotherapeutic approaches against MS.

Mannan (a poly mannose), which targets the mannose receptor expressed on dendritic cells and macrophages, has been used to target antigens to dendritic cells to stimulate appropriate immune responses. Mannan targets antigens to the mannose receptor for efficient uptake and presentation for $\mathrm{T}$ cell stimulation and also activates dendritic cells via toll-like receptor-4 (19). Whether mannan is conjugated to proteins or peptides in its oxidized (comprising aldehydes) or reduced (aldehydes reduced to alcohols) form, both bind to the mannose receptor efficiently; however, the stimulation of cytokines secreted by dendritic cells varies considerably, with reduced mannan inducing Th2 cytokines and oxidized mannan inducing Th1 cytokines (20). In in vivo studies, mice immunized with oxidized mannan-MUC1 (a tumor associated antigen) fusion protein are protected against the challenge of MUC1 expressing tumors, and in established tumors, oxidized mannan-MUC1 is able to reverse established tumors (21, 22). Similarly, in MUC1 transgenic mice oxidized mannan-MUC1 was immunogenic (23). Either a Th1 response (IL-2, IFN-gamma, 
IL-12, TNF-alpha, and IgG2a antibodies) or Th2 response (IL-4, IL-10, and TGF-beta and IgG1 antibodies) is induced depending on mode of conjugation, oxidized or reduced mannan (21, 22, 24). Other cytokines (IL-5, IL-6, IL-13, IL-15, and IL-18) are also secreted with either oxidized or reduced-mannan conjugates (24-26). In addition to Th1/Th2 type responses to MUC1 in mice, similar responses have been demonstrated in humans (27) and monkeys (28) with MUC1 protein and to an Anaplasma marginale MSP-1 peptide in cows (29). Since reduced mannan has the ability to induce Th2 responses, it was conceivable to use reduced-mannan conjugated to MBP peptides, with the idea being that Th2 cytokines would divert the Th1 cytokines in MS. Hence, the use of altered peptide ligands (APLs) to alter responses of the wild type peptide, in combination with reduced mannan constitutes a novel strategy for the immunotherapy of MS.

We previously demonstrated that linear and cyclic substituted APLs based on $\mathrm{MBP}_{83-99}$ and $\mathrm{MBP}_{87-99}$ epitopes, with single or double mutations at positions 91 and 96 as being the crucial TCR contact residues, conjugated to reduced mannan via the keyhole limpet hemocyanin $(\mathrm{KLH})$ as a linker diverts the

Table 1 | Summary of T cell proliferative, cytokine, and antibody responses.

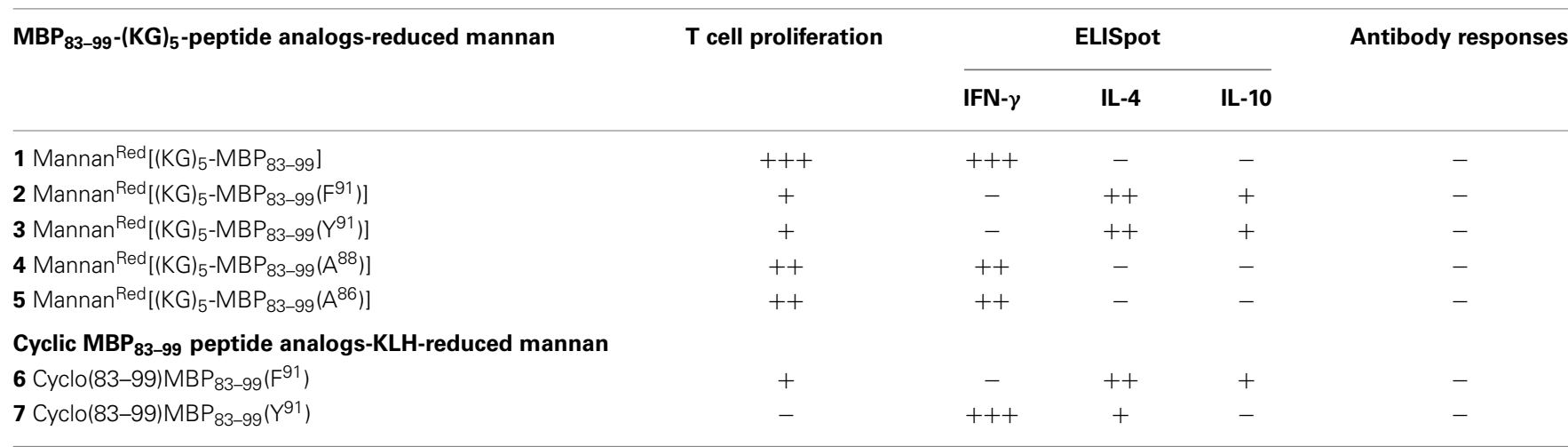

+++ , very strong; ++ , intermediate; + , weak; -, negative.

Reduced Mannan Conjugates

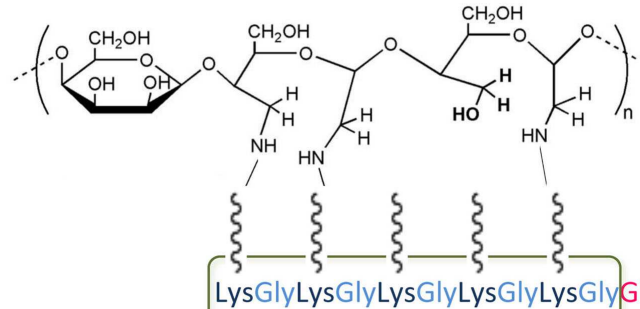

GluAsnProValValHisPhePhe PheAsnlleValThrProArgThrPro
Basic

- Non-polar (hydrophobic)

- Polar, uncharged

Acidic

Analogue 2: Mannan ${ }^{\text {Red }}\left[(\mathrm{KG})_{5}-\mathrm{MBP}_{83-99}\left(\mathrm{~F}^{91}\right)\right]$

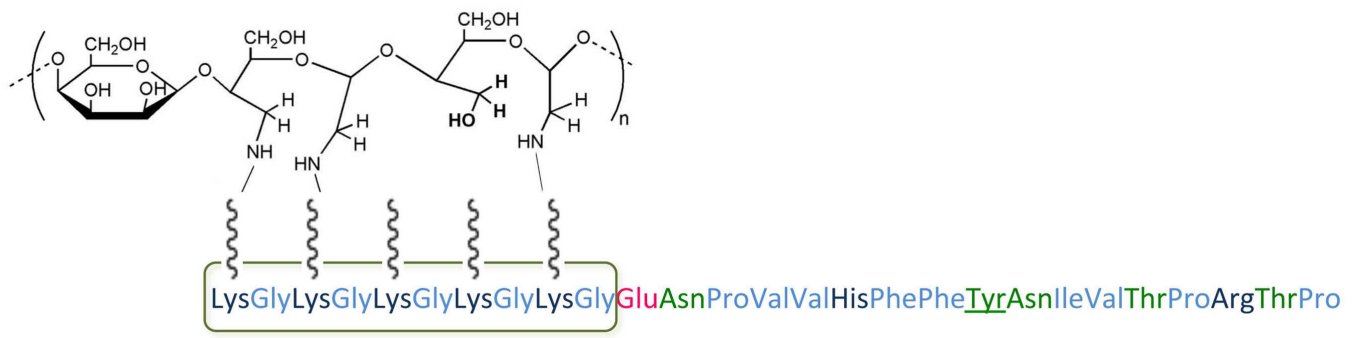

Analogue 3: Mannan ${ }^{\text {Red }}\left[(\mathrm{KG})_{5}-\mathrm{MBP}_{83-99}\left(\mathrm{Y}^{91}\right)\right]$

FIGURE 1 | Schematic presentation of analog 2: $\operatorname{Mannan}^{\text {Red }}\left[(K G)_{5}-\mathbf{M B P}_{83-99}\left(\mathbf{F}^{91}\right)\right]$ and analog 3: $\mathbf{M a n n a n}^{\text {Red }}\left[\left(K_{G}\right)_{5}-\mathbf{M B P}_{83-99}\left(\mathbf{Y}^{91}\right)\right]$. The polarity of each amino acid is colory presented. 
immune response from Th1 to Th2 enhancing the induction of anti-inflammatory cytokines IL-4 and IL-10 (30-35). In these studies, the cyclic and linear APLs were conjugated to KLH followed by conjugation to oxidized mannan and followed by its reduction to result in reduced-mannan conjugates. KLH was used as a linker between the peptide analogs and mannan as it is known that KLH has the ability to stimulate/enhance immunity (30-34), especially the induction of antibody responses. It was shown that antibodies were highly induced some of which did or did not cross react with the native peptide (30-34). KLH is a large molecular weight protein and the conjugate is highly heterogeneous and for future commercialization prospects following human clinical trials, would be highly complicated. In order to design a more precise immunotherapeutic with a smaller bridge, between peptide and reduced mannan, linear mutated $\mathrm{MBP}_{83-99}$ peptide analogs, with specific TCR substitutions, were conjugated to reduced mannan via a 10 amino acid bridge, $[\text { LysGly }]_{5}\left[(\mathrm{KG})_{5}\right]$ at the $\mathrm{N}$-terminus of each peptide. In addition, the use of a smaller bridge like $(\mathrm{KG})_{5}$ rather than KLH could potentially reduce antibody responses against the immunizing peptide, which could otherwise be a problem in human clinical trials. In this respect, a number of APL analogs with $(\mathrm{KG})_{5}$ at its $\mathrm{N}$-terminus and conjugated to reduced

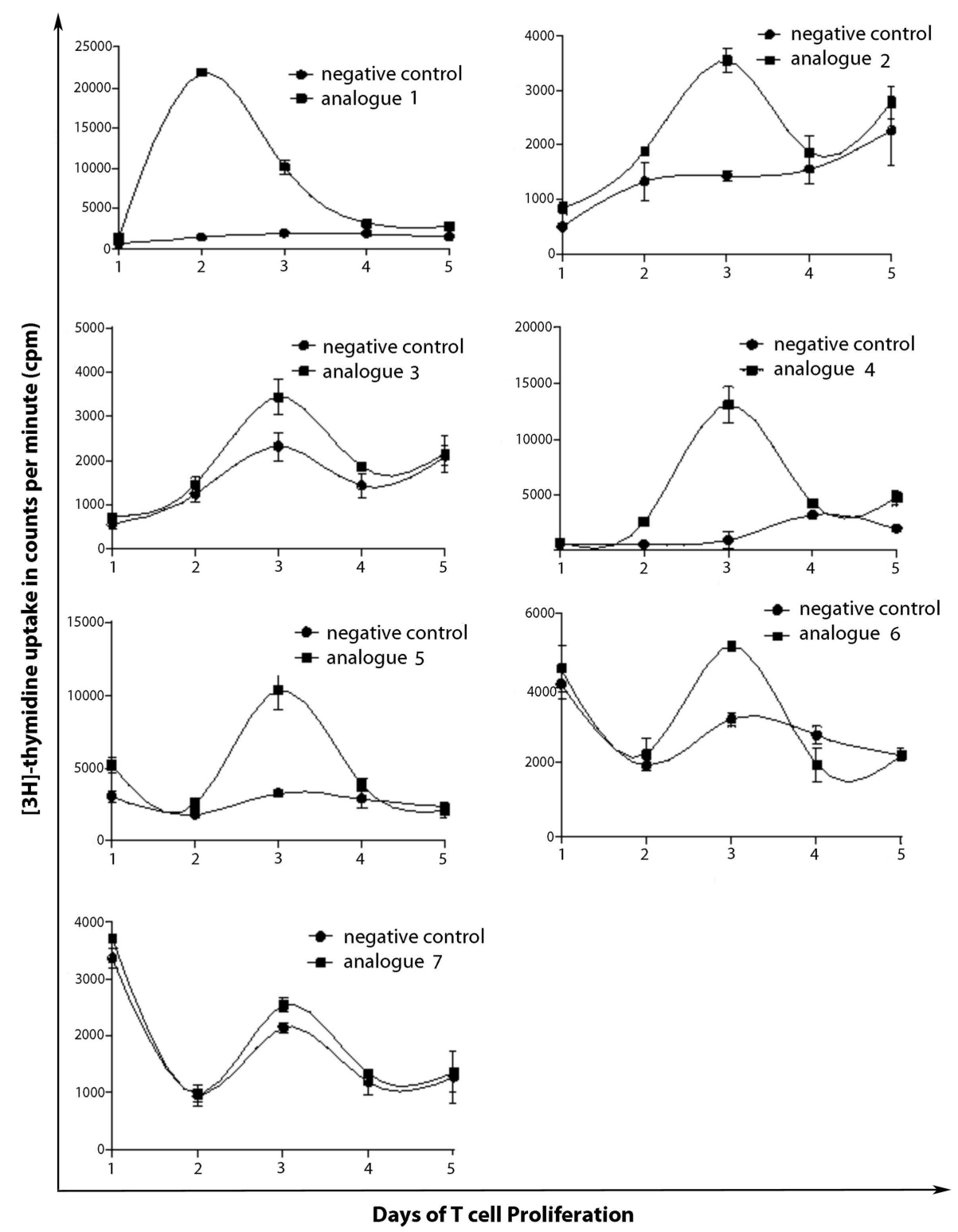

FIGURE 2 |T cell proliferation of spleen cells from immunized mice. SJL/J mice were immunized using linear $\mathrm{MBP}_{83-99}$ analogs conjugated to reduced mannan via (KG) 5 bridge (analogs 1-5) and cyclic $\mathrm{MBP}_{83-99}$ analogs conjugated to reduced mannan via KLH linker (analogs $\mathbf{6}$ and $\mathbf{7}$ ). ConA (internal positive control) yielded proliferation of more than $90,000 \mathrm{cpm}$ and was excluded from the figures and no peptide (cells alone) was used as background negative control. 
mannan were studied in SJL/J mice for their ability to induce immune responses, especially, T cell proliferation, IFN-gamma, IL-4, and IL-10 cytokine secretion and antibody responses.

\section{RESULTS AND DISCUSSION}

In this study, we have designed and synthesized mutant peptide analogs based on the 83-99 epitope of MBP, replacing the Lys at position 91 with a hydrophobic and aromatic amino acid (Phe or Tyr) or Val, His at positions 86 and 88 with Ala (Table 1). It is known that $\mathrm{Val}^{88}$ and $\mathrm{Lys}^{91}$ play a pivotal role in the interaction with the TCR and the activation of encephalitogenic T cells that are responsible for EAE and MS induction. The $(\mathrm{KG})_{5}$ bridge was used in the $\mathrm{N}$ terminal of each linear peptide analog for conjugation with reduced mannan (Table 1; Figure 1). In our previous studies, the use of KLH bridge-mannan conjugates was less stable compared with reduced-mannan conjugation via $(\mathrm{KG})_{5}$ bridge. Two cyclic analogs were also synthesized with head-to-tail cyclization and mutation at position 91 (Phe or Tyr). The cyclic peptide analogs 6, 7 were conjugated with mannan via the KLH linker. It is known that the cyclic analogs are more stable in proteolytic degradation compared to linear counterparts (36). The backbone cyclization of peptides has been demonstrated to improve biological activity, in vivo stability and to reduce conformation freedom (37).

$\mathrm{SJL} / \mathrm{J}$ mice $\left(\mathrm{I}-\mathrm{A}^{\mathrm{s}}\right)$ is commonly used for the evaluation of MBP peptide analogs, as both murine $\mathrm{I}-\mathrm{A}^{\mathrm{s}}$ and human HLA-DR2 bind to $\mathrm{MBP}_{83-99}$ peptides. The synthesized $\mathrm{MBP}_{83-99}-(\mathrm{KG})_{5}$ analogs conjugated to reduced mannan were used to immunize SJL/J mice. Immunized mice with analog 1 , induced very strong $\mathrm{T}$ cell proliferative responses after recall peptide in vitro. Peak proliferation was on day 2 , which declined by day $3(p<0.001)$, and were background levels by day 4 . Analogs 4 and 5 induced intermediate $\mathrm{T}$ cell proliferative responses $(p<0.001)$. Analogs 2,3 , and $\mathbf{6}$, induced weak $\mathrm{T}$ cell proliferative responses, which were specific and significantly above background levels $(p<0.001)$. Peptide 7 did not stimulate $\mathrm{T}$ cell responses in SJL/J mice (Table 1; Figure 2).

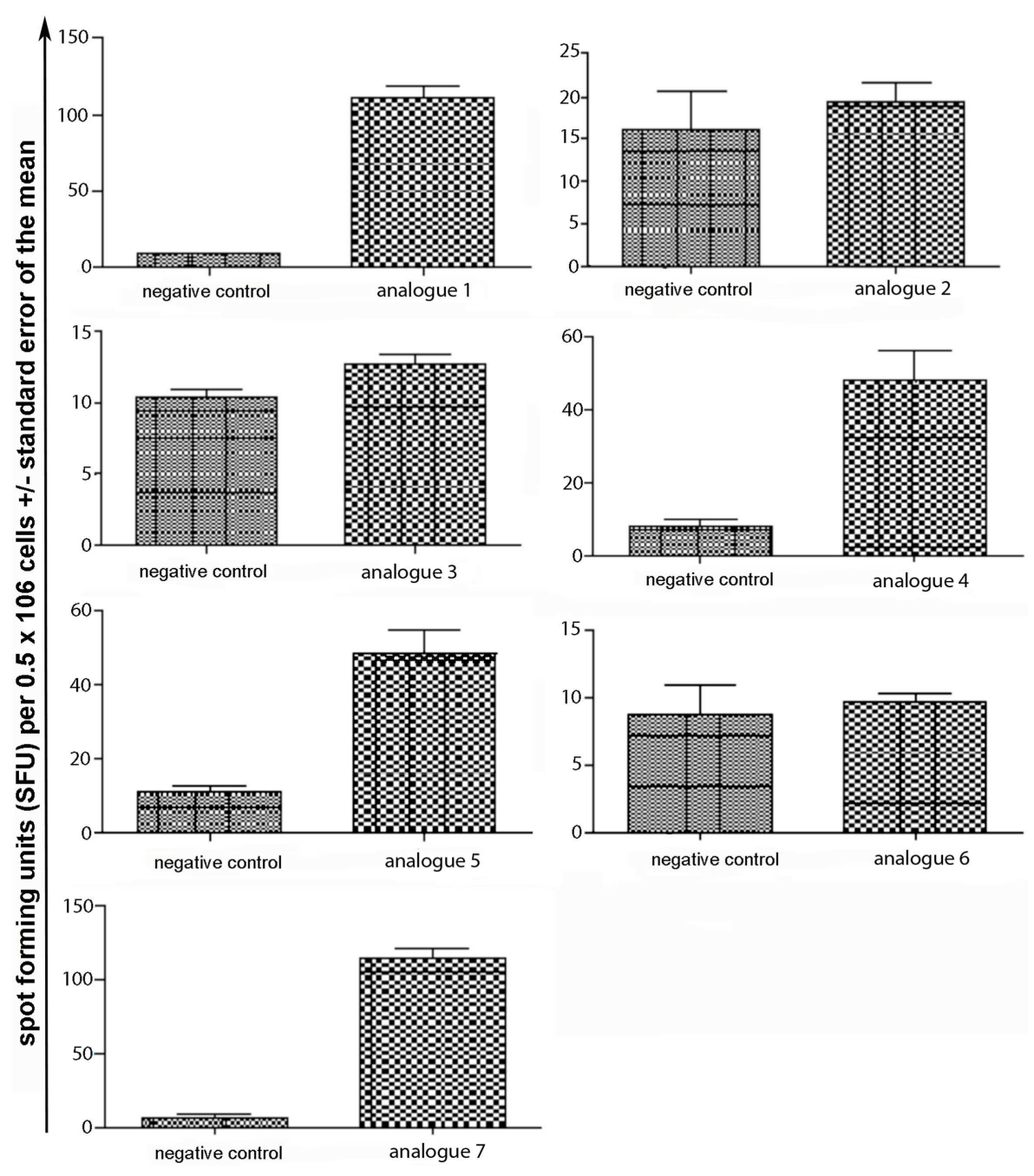

FIGURE 3 | IFN-gamma ELISpot assay of spleen cells from immunized mice. SJL/J mice were immunized using linear $\mathrm{MBP}_{83-99}$ analogs conjugated to reduced mannan via $(K G)_{5}$ bridge (analogs $\mathbf{1 - 5}$ ) and cyclic $\mathrm{MBP}_{83-99}$ analogs conjugated to reduced mannan via KLH linker (analogs 6 and 7). No peptide (cells alone) was used as background negative control. ConA was used as an internal positive control to ensure cells were reactive, not shown. 
Spleen cells were isolated and assessed for $\mathrm{T}$ cell cytokine production (IFN-gamma, IL-4, IL-10) using the ELISpot assay (Table 1; Figures 3-5). Immunized mice with analogs 1 and 7 induced very strong IFN-gamma cytokine responses after recall peptide in vitro $(p<0.001)$. Analogs 4 and 5 induced intermediate IFN-gamma cytokine responses $(p<0.001)$. Analogs 2,3 , and 6 did not stimulate IFN-gamma cytokine responses in SJL/J mice (Figure 3). Immunized mice with analogs 2, 3, and 6 induced intermediate IL-4 cytokine responses $(p<0.001)$. Analog 7 induced weak IL-4 cytokine response, which was significant above background. Analogs 1, 4, and 5 did not stimulate IL-4 cytokine responses in SJL/J mice (Figure 4). Moreover, analogs 2, 3, and 6 induced very weak IL-10 cytokine response, which were significant above background $(p<0.05)$. All other peptides did not stimulate IL-4 cytokine responses in SJL/J mice (Figure 5). Interestingly, none of the peptide analogs generated antibody responses as measured by reactivity to native peptide and to peptide analog, from serum from immunized mice (Table 1).

\section{CONCLUSION}

In previous studies, we used KLH as a linker between mannan and linear peptide. However, in an attempt to develop more defined conjugates for clinical use, we used a small 10 amino acid bridge $(\mathrm{KG})_{5}$, to link mannan to linear APL. In this regard, the mannan ${ }^{\text {Red }}\left[(\mathrm{KG})_{5}-\mathrm{MBP}_{83-99}\right]$ analog (native epitope) induced very strong $\mathrm{T}$ cell proliferative and IFN-gamma cytokine secretion responses. The mannan ${ }^{\operatorname{Red}}\left[(\mathrm{KG})_{5}-\mathrm{MBP}_{83-99}\left(\mathrm{~F}^{91}\right)\right]$ and cyclic $\mathrm{MBP}_{83-99}\left(\mathrm{~F}^{91}\right)$ did not induce IFN-gamma responses and antibodies but induced IL- 4 and IL-10 cytokines. The mannan ${ }^{\text {Red }}$ $\left[(\mathrm{KG})_{5}-\mathrm{MBP}_{83-99}\left(\mathrm{Y}^{91}\right)\right]$ did not induce IFN-gamma responses and antibodies but induced IL-4 and IL-10 cytokine; however, the cyclic counterpart cyclo(83-99) $\mathrm{MBP}_{83-99}\left(\mathrm{Y}^{91}\right)$ generated strong IFN- $\gamma$ cytokine the same as for the mannan ${ }^{\operatorname{Red}}\left[(\mathrm{KG})_{5}\right.$ $\left.\mathrm{MBP}_{83-99}\left(\mathrm{~A}^{88}\right)\right]$ and mannan ${ }^{\mathrm{Red}}\left[(\mathrm{KG})_{5}-\mathrm{MBP}_{83-99}\left(\mathrm{~A}^{86}\right)\right]$. None of the peptide analogs generated antibody responses. Of note, here we used $\mathrm{KLH}$ as a linker between mannan and cyclic peptide, as $(\mathrm{KG})_{5}$ bridge would not allow conjugation in the
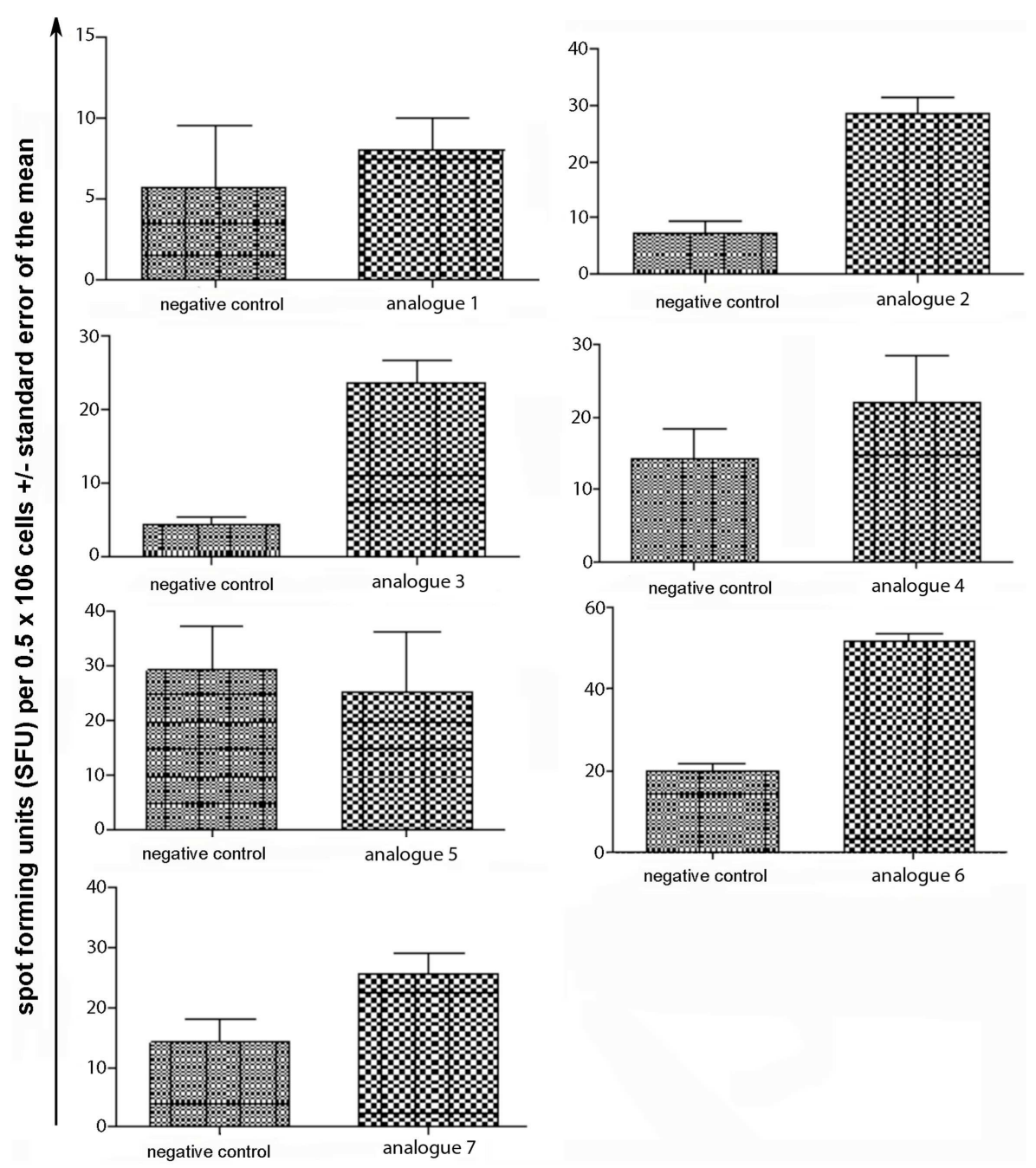

FIGURE 4 | IL-4 ELISpot assay of spleen cells from immunized mice. $\mathrm{SJL} / \mathrm{J}$ mice were immunized using linear $\mathrm{MBP}_{83-99}$ analogs conjugated to reduced mannan via $(K G)_{5}$ bridge (analogs $\mathbf{1 - 5}$ ) and cyclic $\mathrm{MBP}_{83-99}$ analogs conjugated to reduced mannan via KLH linker (analogs 6 and 7). No peptide (cells alone) was used as background negative control. ConA was used as an internal positive control to ensure cells were reactive, not shown. 


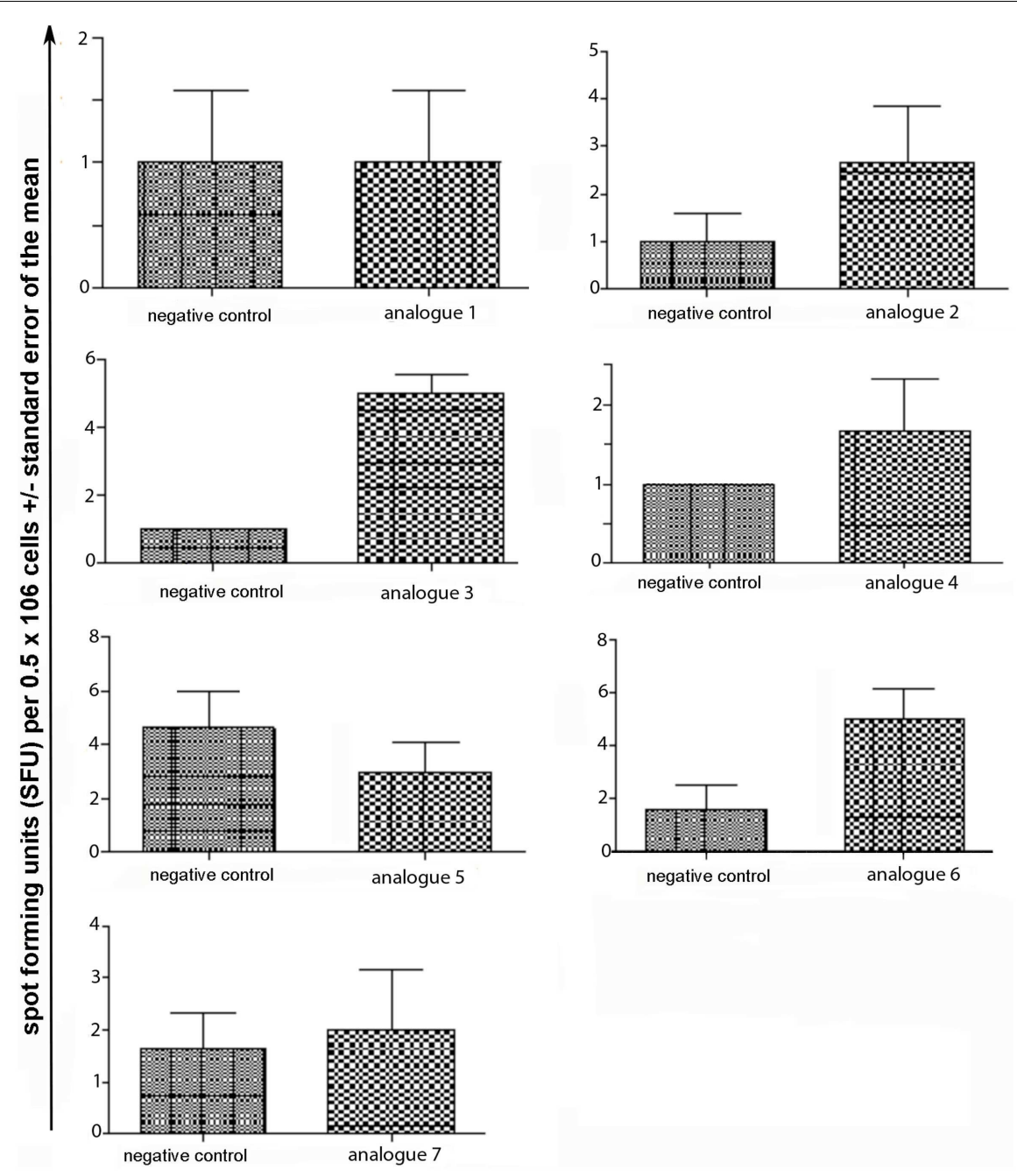

FIGURE 5 | IL-10 ELISpot assay of spleen cells from immunized mice. $\mathrm{SJL} / \mathrm{J}$ mice were immunized using linear $\mathrm{MBP}_{83-99}$ analogs conjugated to reduced mannan via $(K G)_{5}$ bridge (analogs 1-5) and cyclic $\mathrm{MBP}_{83-99}$ analogs conjugated to reduced mannan via KLH linker (analogs 6 and 7). No peptide (cells alone) was used as background negative control. ConA was used as an internal positive control to ensure cells were reactive, not shown. cyclic peptide form. In conclusion, the analogs 1, 2, and 6, $\operatorname{mannan}^{\operatorname{Red}}\left[(\mathrm{KG})_{5}-\mathrm{MBP}_{83-99}\left(\mathrm{~F}^{91}\right)\right]$, cyclic $\mathrm{MBP}_{83-99}\left(\mathrm{~F}^{91}\right)$, and linear mannan ${ }^{\text {Red }}\left[(\mathrm{KG})_{5}-\mathrm{MBP}_{83-99}\left(\mathrm{Y}^{91}\right)\right]$, respectively, yielded the best immunological profile (Table 1) and are the most promising candidates for further studies in vivo in EAE studies, in humanized mice and in vitro using human $\mathrm{T}$ cell clones specific for $\mathrm{MBP}_{83-99}$ immunodominant epitope. Similar to our previous studies, using $\mathrm{KLH}$ as a linker between mannan and linear peptides, the more defined $(\mathrm{KG})_{5}$ bridge presented here, induce specific immune responses. These peptides constitute novel analogs for further immunotherapeutic studies in animal models and possibly in human clinical trials.

\section{EXPERIMENTAL PROCEDURES}

\section{SOLID PHASE PEPTIDE SYNTHESIS OF LINEAR AND CYCLIC ANALOGS}

Peptides (Table 1) were synthesized under microwave irradiation conditions $(38,39)$, following the Fmoc/tBu methodology, using the standard the $N, N^{\prime}$-diisopropyl-carbodiimide (DIC) and 1-hydroxybenzotriazol (HOBt) as coupling reagents (40-43). The head-to-tail cyclization of analogs 6 and 7 was achieved using $O$-benzotriazol-1-yl- $N, N, N^{\prime}, N^{\prime}$-tetramethyluronium tetrafluoro borate/1-hydroxy 7-azabenzotriazol (TBTU/HOAt) and 2,4,6collidine in dry dimethyformamide (DMF) (Schemes 1 and 2) $(36,41-45)$. The final peptides were further purified using semipreparative reverse phase high performance liquid chromatography (RP-HPLC). The purity of peptides was higher than $98 \%$ as determined by analytical RP-HPLC and their identification was achieved by electron spray ionization mass spectrometry (ESI-MS).

\section{CONJUGATION OF REDUCED MANNAN TO LINEAR AND CYCLIC MBP $_{\text {83-99 }}$ PEPTIDE ANALOGS}

The conjugation between peptide to reduced mannan was achieved following a protocol earlier described for protein or peptide-KLH conjugations $(21,22,31,34)$. Briefly, 14 mg mannan (poly mannose from Saccharomyces cerevisiae, Sigma-Aldrich 


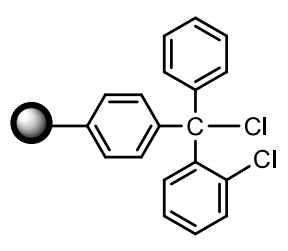

1. Fmoc-Pro-OH, DIPEA

2. $25 \%$ piperidine/DMF

H-Pro-O-O

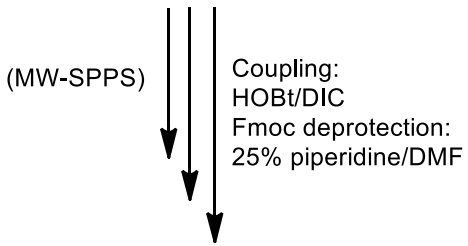

H-Lys(Boc)-Gly-Lys(Boc)-Gly-Lys(Boc)-Gly-Lys(Boc)-Gly-Lys(Boc)-Gly-Glu(tBu)-Asn(Trt)Pro-X ${ }_{1}$-Val-X $\mathbf{X}_{2 a}$-Phe-Phe-X $\mathbf{3}_{3 \mathrm{a}}$-Asn(Trt)-lle-Val-Thr(tBu)-Pro-Arg(Pbf)-Thr(tBu)-Pro-O-O

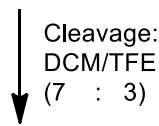

H-Lys(Boc)-Gly-Lys(Boc)-Gly-Lys(Boc)-ly-Lys(Boc)-Gly-Lys(Boc)-Gly-Glu(tBu)-Asn(Trt)Pro- $\mathbf{X}_{1}-V_{a l}-\mathbf{X}_{2 a}$-Phe-Phe- $\mathbf{X}_{3 a}$-Asn(Trt)-Ile-Val-Thr(tBu)-Pro-Arg(Pbf)-Thr(tBu)-Pro-OH

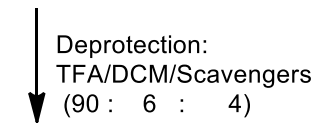

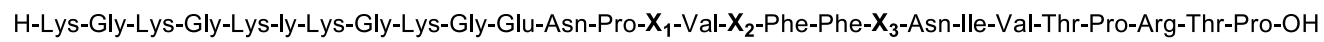

\author{
$\mathrm{X}_{1}$ : Val, Ala \\ $X_{2 a}: \operatorname{His}(T r t)$, Ala \\ $\mathbf{X}_{2}$ : His, Ala \\ $\mathbf{X}_{3 \mathrm{a}}$ : Lys(Boc), Phe, Tyr(tBu) \\ $\mathrm{X}_{3}$ : Lys, Phe, Tyr
}

SCHEME 1 | Synthetic procedure of linear peptide analogs based on the $\mathrm{MBP}_{83-99}$ immunodominant epitope

Ltd., was dissolved in $1 \mathrm{ml}$ phosphate buffer, $\mathrm{pH}$ 6.0, and oxidized to polyaldehyde by treating with sodium periodate. Ethanediol was then added to the mixture and the mixture was passed through a PD-10 column (Sephadex G-25 M column, Pharmacia Biotech., Sweden) equilibrated with $0.1 \mathrm{M}$ bicarbonate buffer $\mathrm{pH} 9.0$ and the oxidized mannan fraction collected. Conjugation of linear peptide analogs-(KG) $)_{5}$ (analogs 1-5) and cyclic analogs-KLH (analogs 6 and 7) to oxidized mannan was performed in bicarbonate buffer, pH 9.0, in dark (Table 1; Figure 1). The addition of sodium borohydride for $6 \mathrm{~h}$ at room temperature resulted in reduced-mannan conjugates (46). The final MBP peptide analogs conjugated with mannan were analyzed by SDS PAGE (44).

\section{MICE AND IMMUNIZATIONS}

Female 6- to 8-week-old SJL/J mice, used in all experiments, were purchased from Walter and Eliza Hall Institute (VIC, Australia) and housed at the Biological Research Laboratory at Burnet Institute (Austin Campus), Heidelberg, VIC, Australia. SJL/J mice were immunized with $50 \mu \mathrm{g}$ of each peptide analog (Table 1) conjugated with reduced mannan, twice on days 0 and 14, intradermally (at the base of the tail). All studies were reviewed and approved by Austin Health and Alfred Health animal ethics committee.

\section{IMMUNOLOGICAL ASSAYS ELISpot}

Spleen cells from immunized SJL/J mice were isolated 14 days after the last immunization and assessed by ELISpot for IFN- $\gamma$, IL-4, and IL-10 secretion by T cells. IFN- $\gamma$ ELISpot assay was performed on MultiScreen-IP Filter Plate (MAIP S4510) with hydrophobic PVDF filters (Millipore, UK), while IL-4 and IL-10 ELISpot assays were performed on MultiScreen-HA Filter Plate (MAHA S4510) with mixed cellulose esters filters (Millipore, UK). MAIP S4510 plates were pre-wetted with $50 \mu$ l of $70 \%$ ethanol, washed five times with $200 \mu \mathrm{l}$ of sterile phosphate buffered saline (PBS) and coated with $70 \mu \mathrm{l}$ of $5 \mu \mathrm{g} / \mathrm{ml}$ anti-IFN- $\gamma$ capture antibody, AN18 (Mabtech, Australia) in PBS and incubated at $4^{\circ} \mathrm{C}$ overnight $(\mathrm{O} / \mathrm{N})$. Seventy microliters of $5 \mu \mathrm{g} / \mathrm{ml}$ anti-IL-4 capture antibody (Mabtech, Australia) were added directly to MAHA S4510 plates and incubated at $4{ }^{\circ} \mathrm{C} \mathrm{O} / \mathrm{N}$ without $70 \%$ ethanol treatment. Following five washes with PBS, plates were blocked by adding $200 \mu \mathrm{l}$ of culture media (supplemented with $2.5 \%$ FCS) and incubated for $2 \mathrm{~h}$ at $37^{\circ} \mathrm{C}$. The blocking media was discarded and $10 \mu \mathrm{g} / \mathrm{ml}$ recall peptides were added into each defined well. Con A $(1.0 \mu \mathrm{g} / \mathrm{ml})$ was used as internal positive control and no peptide (cells alone) as negative control. Triplicate wells were set 


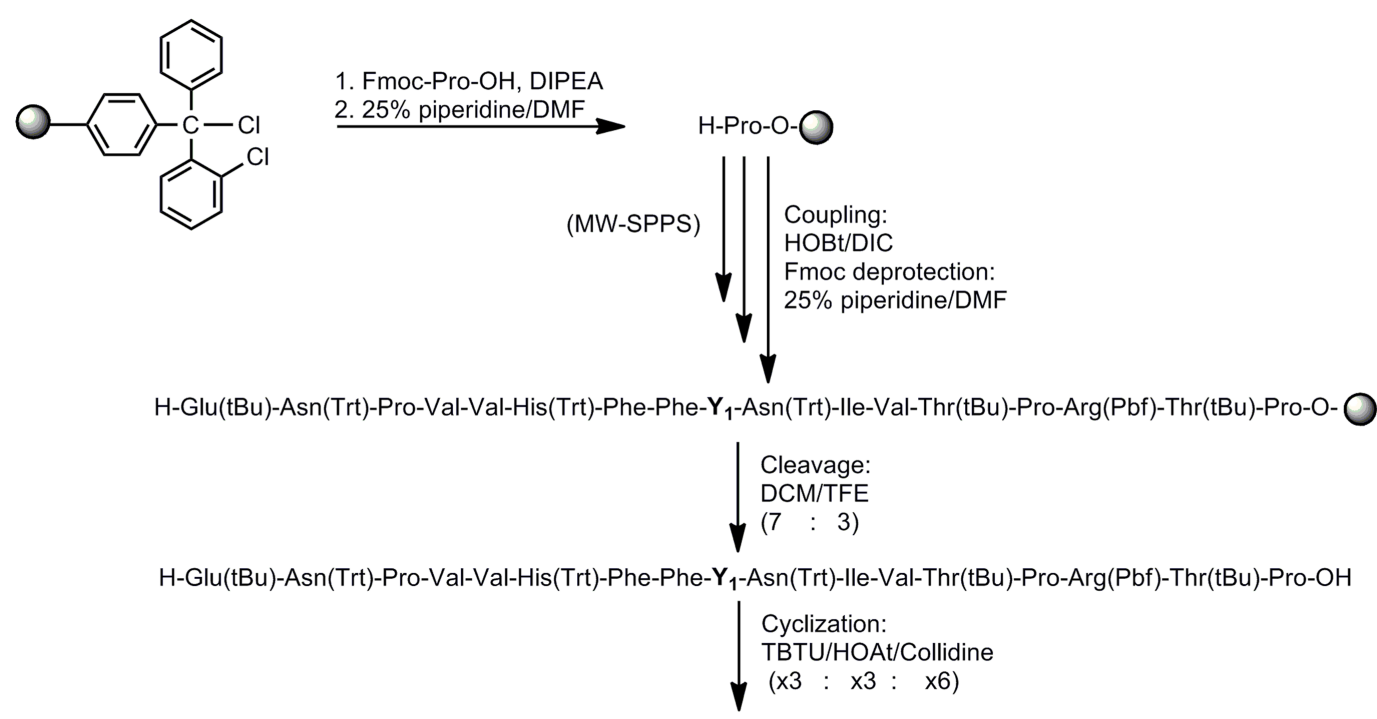

Glu(tBu)-Asn(Trt)-Pro-Val-Val-His(Trt)-Phe-Phe-Y1-Asn(Trt)-lle-Val-Thr(tBu)-Pro-Arg(Pbf)-Thr(tBu)-Pro

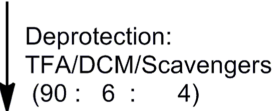

Glu-Asn-Pro-Val-Val-His-Phe-Phe-Y-Asn-Ile-Val-Thr-Pro-Arg-Thr-Pro

$\mathbf{Y}_{1}$ : Phe, Tyr(tBu)

Y : Phe, Tyr

SCHEME 2 | Synthetic procedure of cyclic peptide analogs based on the MBP $_{83-99}$ immunodominant epitope.

up for each condition. About $5 \times 10^{5}$ spleen cells in $100 \mu \mathrm{l}$ culture media were seeded into each well and incubated at $37^{\circ} \mathrm{C}$ for $18 \mathrm{~h}$ (IFN- $\gamma$ ), or $24 \mathrm{~h}$ (IL-4), or $48 \mathrm{~h}$ for IL-10. Plates were washed five times with PBS/0.05\% Tween 20 followed by five times with PBS and incubated for $2 \mathrm{~h}$ at RT with anti-murine IFN- $\gamma$, IL-4, or IL-10 monoclonal antibody-biotin. Plates were washed and streptavidin alkaline phosphatase (streptavidin-ALP) was added at $1.0 \mu \mathrm{g} / \mathrm{ml}$ and incubated for $2 \mathrm{~h}$ at RT. Spots of activity were detected using a colorimetric AP kit (Biorad, Hercules, CA USA) and counted using an AID ELISpot plate reader (Autoimmun Diagnostika GmbH, Germany). Data are presented as mean spot forming units (SFU) per $0.5 \times 10^{6}$ cells \pm SEM.

\section{Proliferation}

Spleen cells from immunized SJL/J mice were isolated 25-28 days after immunization and assessed by $\mathrm{T}$ cell proliferation assay. About $1 \times 10^{5}$ spleen cells in $100 \mu \mathrm{l}$ of culture media were seeded into 96 well $U$-bottom plates and incubated for $1-6$ days at $37^{\circ} \mathrm{C}$ in the presence of recall peptide $(10 \mu \mathrm{g} / \mathrm{ml})$, ConA (internal control), or no peptide (negative control). ConA (internal positive control) yielded proliferation of more than $90,000 \mathrm{cpm}$ and was excluded from the figures and no peptide (cells alone) was used as background negative control. Proliferation was assessed by adding $1 \mu \mathrm{Ci}$ of $\left[{ }^{3} \mathrm{H}\right]$-thymidine per well to one plate per time point (days 1-6). Cells were incubated for $6 \mathrm{~h}$ before harvesting onto glass fiber filters. $\left[{ }^{3} \mathrm{H}\right]$-thymidine uptake was measured using a $\beta$-scintillation counter (Top Count Gamma Counter, Packard, USA).

\section{Statistical analysis}

Mean values were compared using an unpaired $t$-test and one-way ANOVA. ${ }^{*} p<0.05$ indicates a significant difference, ${ }^{* *} p<0.001$ indicates highly significant difference.

\section{ACKNOWLEDGMENTS}

This work is financially supported by the "Cooperation" program 09SYN-609-21, (O.P. Competitiveness and Entrepreneurship EPAN II, ROP Macedonia - Thrace, ROP Crete and Aegean Islands, ROP Thessaly - Mainland Greece - Epirus, ROP Attica). The authors would like to thank Eldrug S.A. for providing access to the CEM Liberty automated microwave peptide synthesizer.

\section{REFERENCES}

1. Martin R, McFarland HF, McFarlin DE. Immunological aspects of demyelinating diseases. Annu Rev Immunol (1992) 10:153-87. doi:10.1146/annurev.iy.10. 040192.001101

2. Steinman L. Multiple sclerosis: a coordinated immunological attack against myelin in the central nervous system. Cell (1996) 85:299-302. doi:10.1016/ S0092-8674(00)81107-1 
3. Noseworth JH. Progress in determining the causes and treatment of multiple sclerosis. Nature (1999) 399:40-7. doi:10.1038/399a040

4. Zamvil SS, Steinman L. The T lymphocyte in experimental allergic encephalomyelitis. Annu Rev Immunol (1990) 8:579-621. doi:10.1146/annurev. iy.08.040190.003051

5. Ota K, Matsui M, Milford EL, Mackin GA, Weiner HL, Hafler DA. T-cell recognition of an immunodominant myelin basic protein epitope in multiple sclerosis. Nature (1990) 346:183-7. doi:10.1038/346183a0

6. Pette M, Fujita K, Wilkinson D, Altmann DM, Trowsdale J, Giegerich G, et al. Myelin autoreactivity in multiple sclerosis: recognition of myelin basic protein in the context of HLA-DR2 products by T lymphocytes of multiple-sclerosis patients and healthy donors. Proc Natl Acad Sci U S A (1990) 87:7968-72. doi:10.1073/pnas.87.20.7968

7. Martin R, Jaraquemada D, Flerlage M, Richert J, Whitaker J, Long EO, et al. Fine specificity and HLA restriction of myelin basic protein-specific cytotoxic T cell lines from multiple sclerosis patients and healthy individuals. J Immunol (1990) 145:540-8.

8. Wucherpfennig KW, Sette A, Southwood S, Oseroff C, Matsui M, Strominger JL, et al. Structural requirements for binding of an immunodominant myelin basic protein peptide to DR2 isotypes and for its recognition by human T cell clones. J Exp Med (1994) 179:279-90. doi:10.1084/jem.179.1.279

9. Wucherpfennig KW, Zhang J, Witek C, Matsui M, Modabber Y, Ota K, et al. Clonal expansion and persistence of human T cells specific for an immunodominant myelin basic protein peptide. J Immunol (1994) 152:5581-92.

10. Mantzourani ED, Mavromoustakos TM, Platts JA, Matsoukas JM, Tselios TV. Structural requirements for binding of myelin basic protein (MBP) peptides to MHC II: effects in immune regulation. Curr Med Chem (2005) 12(13):1569-87. doi:10.2174/0929867054039053

11. Wucherpfennig KW, Hafler DA, Strominger JL. Structure of human T-cell receptors specific for an immunodominant myelin basic protein peptide: positioning of T-cell receptors on HLA-DR2/peptide complexes. Proc Natl Acad Sci U S A (1995) 92:8896-900. doi:10.1073/pnas.92.19.8896

12. Gauthier L, Smith KJ, Pyrdol J, Kalandadze A, Strominger JL, Wiley DC, et al. Expression and crystallization of the complex of HLA-DR2 (DRA, DRB1 ${ }^{\star} 1501$ ) and an immunodominant peptide of human myelin basic protein. Proc Natl Acad Sci U S A (1998) 95:11828-33. doi:10.1073/pnas.95.20.11828

13. Smith KJ, Pyrdol J, Gauthier L, Wiley DC, Wucherpfennig KW. Crystal structure of HLA-DR2 $\left(\mathrm{DRA}^{\star} 0101, \mathrm{DRB}^{\star}{ }^{\star} 1501\right)$ complexed with a peptide from human myelin basic protein. J Exp Med (1998) 188:1511-20. doi:10.1084/jem. 188.8.1511

14. Hahn M, Nicholson NJ, Pyrdol J, Wucherpfennig KW. Unconventional topology of self-peptide-major histocompability complex binding by a human autoimmune T cell receptor. Nat Immunol (2005) 6:490-6. doi:10.1038/ ni1 187

15. Potamitis C, Matsoukas MT, Tselios T, Mavromoustakos T, Golič Grdadolnik S. Conformational analysis of the $\mu \beta \rho(83-99)$ (Phe (91)) and $\mu \beta \rho$ (83-99) (Tyr (91)) peptide analogues and study of their interactions with the HLA-DR2 and human TCR receptors by using molecular dynamics. J Comput Aided Mol Des (2011) 25(9):837-53. doi:10.1007/s10822-011-9467-4

16. Li Y, Huang Y, Lue J, Quandt JA, Martin R, Mariuzza RA. Structure of a human autoimmune TCR bound to a myelin basic protein self-peptide and a multiple sclerosis-associated MHC class II molecule. EMBO J (2005) 24:2968-79. doi:10.1038/sj.emboj.7600771

17. Kappos L, Comi G, Panitch H, Oger J, Antel J, Conlon P, et al. Induction of a nonencephalitogenic type $2 \mathrm{~T}$ helper-cell autoimmune response in multiple sclerosis after administration of an altered peptide ligand in a placebo-controlled, randomized phase II trial. The altered peptide ligand in relapsing MS study group. Nat Med (2000) 6:1176-82. doi:10.1038/80525

18. Bielekova B, Goodwin B, Richert N, Cortese I, Kondo T, Afshar G, et al. Encephalitogenic potential of the myelin basic protein peptide (amino acids 83-99) in multiple sclerosis: results of a phase II clinical trial with an altered peptide ligand. Nat Med (2000) 6:1167-75. doi:10.1038/80516

19. Sheng KC, Kalkanidis M, Pouniotis DS, Pietersz GA, Apostolopoulos V. The adjuvanticity of a mannosylated antigen reveals toll-like receptor 4 functionality essential for subset specialization an functional maturation of mouse dendritic cells. J Immunol (2008) 181:2455-64. doi:10.4049/jimmunol.181.4.2455

20. Sheng KC, Pouniotis DS, Wright MD, Tang CK, Lazoura E, Pietersz GA, et al. Mannan derivatives induce phenotypic and functional maturation of mouse dendritic cells. Vaccine (2006) 118:372-83. doi:10.1111/j.1365-2567. 2006.02384.x

21. Apostolopoulos V, Pietersz A, Loveland B, Sandrin M, McKenzie I. Oxidative/reductive conjugation of mannan to antigen selects for T1 or T2 immune responses. Proc Natl Acad Sci U S A (1995) 92(22):10128-32. doi:10.1073/pnas. 92.22.10128

22. Apostolopoulos V, Pietersz A, McKenzie I. Cell-mediated immune responses to MUC1 fusion protein coupled to mannan. Vaccine (1996) 14(9):930-8. doi:10.1016/0264-410X(95)00258-3

23. Acres B, Apostolopoulos V, Balloul JM, Wreschner D, Xing PX, Ali-Hadji D, et al. MUC1-specific immune responses in human MUC1 transgenic mice immunized with various human MUC1 vaccines. Cancer Immunol Immunother (2000) 48:588-94. doi:10.1007/PL00006677

24. Lofthouse SA, Apostolopoulos V, Pietersz GA, Li W, McKenzie IF. Induction of T1 (cytotoxic lymphocyte) and/or T2 (antibody) responses to a mucin-1 tumour antigen. Vaccine (1997) 15:1586-93. doi:10.1016/S0264-410X(97)00077-7

25. Lees CJ, Apostolopoulos V, Acres B, Ong CS, Popovski V, McKenzie IF. The effect of T1 and T2 cytokines on the cytotoxic T cell response to mannan-MUC1. Cancer Immunol Immunother (2000) 48:644-52. doi:10.1007/s002620050013

26. Lees CJ, Apostolopoulos V, Acres B, Ramshaw I, Ramsay A, Ong CS, et al. Immunotherapy with mannan-MUC1 and IL-12 in MUC1 transgenic mice. Vaccine (2000) 19:158-62. doi:10.1016/S0264-410X(00)00065-7

27. Karanikas V, Hwang LA, Pearson J, Ong CS, Apostolopoulos V, Vaughan H, et al. Antibody and T cell responses of patients with adenocarcinoma immunized with mannan-MUC1 fusion protein. J Clin Invest (1997) 100:2783-92. doi:10.1172/JCI119825

28. Vaughan HA, Ho DW, Karanikas VA, Ong CS, Hwang LA, Pearson JM, et al. Induction of humoral and cellular responses in cynomolgus monkeys immunizedwith mannan-human MUC1 conjugates. Vaccine (1999) 17:2740-52. doi:10.1016/S0264-410X(98)00493-9

29. Davis WC, Konzek RL, Haas K, Estes DM, Hamilton MJ, Call DR, et al. Use of the mannan receptor to selectively target vaccine antigens for processing and antigen presentation through the MHC class I and class II pathways. Ann N Y Acad Sci (2002) 969:119-25. doi:10.1111/j.1749-6632.2002.tb04362.x

30. Katsara M, Deraos G, Tselios T, Matsoukas J, Apostolopoulos V. Design of novel cyclic altered peptide ligands of myelin basic protein MBP83-99 that modulate immune responses in SJL/J mice. J Med Chem (2008) 51(13):3971-8. doi:10.1021/jm8000554

31. Katsara M, Yuriev E, Ramsland PA, Deraos G, Tselios T, Matsoukas J, et al. Mannosylation of mutated $\mathrm{MBP}_{83-99}$ peptides diverts immune responses from Th1 to Th2. Mol Immunol (2008) 45(13):3661-70. doi:10.1016/j.molimm.2008. 04.024

32. Katsara M, Yuriev E, Ramsland PA, Deraos G, Tselios T, Matsoukas J, et al. A double mutation of $\mathrm{MBP}_{83-99}$ peptide induces IL-4 responses and antagonizes IFN-gamma responses. J Neuroimmunol (2008) 200(1-2):77-89. doi:10.1016/j. jneuroim.2008.06.013

33. Katsara M, Deraos G, Tselios T, Matsoukas MT, Friligou I, Matsoukas J, et al. Design and synthesis of a cyclic double mutant peptide cyclo(8799) $\left[\mathrm{A}^{91}, \mathrm{~A}^{96}\right] \mathrm{MBP}_{87-99}$ induces altered responses in mice after conjugation to mannan: implications in the immunotherapy of multiple sclerosis. J Med Chem (2009) 52(1):214-8. doi:10.1021/jm801250v

34. Katsara M, Yuriev E, Ramsland PA, Tselios T, Deraos G, Lourbopoulos A, et al. Altered peptide ligands of myelin basic protein $\mathrm{MBP}_{87-99}$ conjugated to reduced mannan modulate immune responses in mice. Immunology (2009) 128:521-33. doi:10.1111/j.1365-2567.2009.03137.x

35. Deraos G, Chatzantoni K, Matsoukas MT, Tselios T, Deraos S, Katsara M, et al. Citrullination of linear and cyclic altered peptide ligands from myelin basic protein $\mathrm{MBP}_{87-99}$ epitope elicits a Th1 polarized response by $\mathrm{T}$ cells isolated from multiple sclerosis patients: implications in triggering disease. J Med Chem (2008) 51(24):7834-42. doi:10.1021/jm800891n

36. Matsoukas J, Apostolopoulos V, Kalbacher H, Papini AM, Tselios T, Chatzantoni $\mathrm{K}$, et al. Design and synthesis of a novel potent myelin basic protein epitope 87-99 cyclic analogue: enhanced stability and biological properties of mimics render them a potentially new class of immunomodulators. J Med Chem (2005) 48:1470-80. doi:10.1021/jm040849g

37. Katsara M, Tselios T, Deraos S, Deraos G, Matsoukas M, Lazoura E, et al. Round and round we go: cyclic peptides in disease. Curr Med Chem (2006) 13:2221-32. doi:10.2174/092986706777935113 
38. Friligou I, Papadimitriou E, Gatos D, Matsoukas J, Tselios T. Microwave-assisted solid-phase peptide synthesis of the 60-110 domain of human pleiotrophin (hPTN) on 2-chlorotrityl resin. Amino Acids (2011) 40(5):1431-40. doi:10.1007/ s00726-010-0753-6

39. Friligou I, Rizzolo F, Nuti F, Tselios T, Evangelidou M, Emmanouil M, et al. Divergent and convergent synthesis of polymannosylated dibranched antigenic peptide of the immunodominant epitope $\operatorname{MBP}(83-99)$. Bioorg Med Chem (2013) 1(21):6718-25. doi:10.1016/j.bmc.2013.08.008

40. Tselios T, Probert L, Kollias G, Matsoukas E, Roumelioti P, Alexopoulos K, et al. Design and synthesis of small semi-mimetic peptides with immunomodulatory activity based on myelin basic protein (MBP). Amino Acids (1998) 14:333-41. doi:10.1007/BF01318852

41. Tselios T, Probert L, Daliani I, Matsoukas E, Troganis A, Gerothanassis IP, et al. Design and synthesis of a potent cyclic analogue of the myelin basic protein epitope $\mathrm{MBP}_{72-85}$ : importance of the $\mathrm{Ala}^{81}$ carboxyl group and of a cyclic conformation for induction of experimental allergic encephalomyelitis. J Med Chem (1999) 42:1170-7. doi:10.1021/jm980250e

42. Tselios T, Daliani I, Deraos S, Thymianou S, Matsoukas E, Troganis A, et al. Treatment of experimental allergic encephalomyelitis (EAE) by a rationally designed cyclic analogue of myelin basic protein (MBP) epitope 72-85. Bioorg Med Chem Lett (2000) 10:2713-7. doi:10.1016/S0960-894X(00)00556-4

43. Tselios T, Daliani I, Probert L, Deraos S, Matsoukas E, Roy S, et al. Treatment of experimental allergic encephalomyelitis (EAE) induced by guinea pig myelin basic protein epitope $72-85$ with a human $\mathrm{MBP}_{87-99}$ analogue and effects of cyclic peptides. Bioorg Med Chem (2000) 8:1903-9. doi:10.1016/S0968-0896(00) 00134-6

44. Tselios TV, Lamari FN, Karathanasopoulou I, Katsara M, Apostolopoulos V, Pietersz GA, et al. Synthesis and study of the electrophoretic behavior of mannan conjugates with cyclic peptide analogue of myelin basic protein using lysineglycine linker. Anal Biochem (2005) 347:121-8. doi:10.1016/j.ab.2005.09.014

45. Tselios T, Apostolopoulos V, Daliani I, Deraos S, Grdadolnik S, Mavromoustakos $\mathrm{T}$, et al. Antagonistic effects of human cyclic $\mathrm{MBP}_{87-99}$ altered peptide ligands in experimental allergic encephalomyelitis and human T-cell proliferation. J Med Chem (2002) 45:275-83. doi:10.1021/jm0102147

46. Pietersz G, Li W, Popovski V, Caruana J, Apostolopoulos V, McKenzie I. Parameters for using mannan-MUC1 fusion protein to induce cellular immunity. Cancer Immunol Immunother (1998) 45(6):321-6. doi:10.1007/s002620050449

Conflict of Interest Statement: Eldrug S.A., funded the project.

Received: 11 November 2014; accepted: 11 March 2015; published online: 07 April 2015. Citation: Day S, Tselios T, Androutsou M-E, Tapeinou A, Frilligou I, Stojanovska L, Matsoukas J and Apostolopoulos V (2015) Mannosylated linear and cyclic single amino acid mutant peptides using a small 10 amino acid linker constitute promising candidates against multiple sclerosis. Front. Immunol. 6:136. doi: 10.3389/fimmu.2015.00136 This article was submitted to Multiple Sclerosis and Neuroimmunology, a section of the journal Frontiers in Immunology.

Copyright (C) 2015 Day, Tselios, Androutsou, Tapeinou, Frilligou, Stojanovska, Matsoukas and Apostolopoulos. This is an open-access article distributed under the terms of the Creative Commons Attribution License (CC BY). The use, distribution or reproduction in other forums is permitted, provided the original author(s) or licensor are credited and that the original publication in this journal is cited, in accordance with accepted academic practice. No use, distribution or reproduction is permitted which does not comply with these terms. 